\title{
SYNERGISTIC APPROACH TO THE CAPITAL ADAPTATION: CAPITAL AS A MULTIFUNCTIONAL DISSIPATION SYSTEM
}

\author{
Oleksandra Ovchynnykova ${ }^{1}$, Kostiantyn Netudykhata ${ }^{2}$
}

\begin{abstract}
The research subject of the paper is the process of capital adapting. The purpose of the article is to present capital as a multifunction dissipation system, which consists of the number of interconnected subsystems that operates being under the influence of destabilizing socio-economic factors. There is still no explicit definition of economic adaptation, and capital is not regarded as a set of tangible and intangible assets. Taking into account that the current operating environment, at both the macro and micro levels, may be characterized as unsustainable, and each system strives to organize itself to achieve the main objective, it is worth considering the process of adaptation, using a synergistic approach. This requires looking at the concept of capital as a multifunctional system, firstly, identifying which economic categories are made as subsystems of capital and which of them form capital, secondly, assessing potential areas of adaptation, thirdly, and identifying where adaptation can be targeted in the first place, fourthly. Determination of priority goals is the task of rapid financial analysis, using the results of strategic analysis it is possible to determine long-term goals of adaptation. Methodology. The article uses methods of empirical knowledge aimed at structuring approaches to the concepts of capital, their selection and analysis. Based on the empirical research, theoretical studies have been carried out. It was used such methods us analysis and synthesis, deduction, abstraction and generalization. The conceptual framework is based on the theoretical developments in various scientific fields that have studied capital, the enterprise, the economic system as an economic category, the concept of adaptation, synergies in the economy, and methods of strategic and financial analysis. By examining and analysing existing approaches to the listed issues, it has become possible to propose a definition of capital adaptation as a multifunctional dissipation system. As a result of the research, it became clear that for sustainable adaptation, it is advisable to use the tools of strategic management, and for instantaneous adaptation tools to ensure the economic and financial security of the enterprise. In the process of writing this research, it became clear that it was necessary to study issues related to the characteristics of subsystems, their assessment and analysis in order to make the adaptation process more multifaceted and effective.
\end{abstract}

Key words: capital, capital adaptation, synergistic approach, economic system, enterprise and entrepreneurship.

JEL Classification: D24, G32, L26, O29, B10

\section{Introduction}

There is still no clear definition of the term "capital adaptation", so the methodology of the process is lack. Adaptation is essential for accommodation organisms to volatile environments (often negative). Similarly, like living organisms, the economic system and its components, like subsystems, have to respond to environmental change and react to them saving a certain balance. The aim of research is to understand what is capital adapting. To this, it is necessary to take the enterprise as a part of the economic system and to pay attention to the way in which economic agents react to potential stimuli. The research problem is as follows: if can capital be considered as a narrow definition, scoring only tangible or intangible values? If it is worth considering capital as manifestations of heterogeneous forms of property, based on what the enterprise is a symbiosis of property, knowledge, skills, experience, business ambitions, practice background? Thus, using the methods of analysis and synthesis of existing approaches to solving declared problems, the article introduces the idea of considering capital as a multifunctional system that shows signs of dissipation and seeks self-organization to adapt to external and

\footnotetext{
Corresponding author:

${ }^{1}$ Petro Mohyla Black Sea National University, Ukraine.

E-mail: ovchynnykovao@gmail.com

ORCID: https://orcid.org/0000-0002-0624-5549

${ }^{2}$ Petro Mohyla Black Sea National University, Ukraine.

E-mail: kostnet1@gmail.com

ORCID: https://orcid.org/0000-0002-5322-4986
} 
internal influences. The logic of material delivery makes it possible to follow the etymology of the development of the "capital" definition, to understand the concept of multifunctionality of capital, to define the concept of adaptation in the enterprise, taking into account factors of tactical and strategic management. According to this, basic tools are proposed to identify "weaknesses" in order to adapt to the environment's fragility.

\section{Development of the capital concept}

The first attempts at scientific analysis of the term "capital" are found in the works of ancient Greek philosophers. In the middle of the 6th century BC, Aristotle proposed to divide the science of housekeeping "Economics" and the science of the art of managing property (capital) - "Chrematistics". Thus, activities aimed at obtaining the necessary benefits are bound to become activities aimed at accumulating those benefits (Palekhova, 2007). The next stage of the study of the definition of capital began almost two thousand years later with the emergence in Western Europe of the 16th century of the Mercantilism Economic School, which sought an answer to the question of what is wealth and how to determine the sources of that wealth (Mochernyi, 2005). The Classical School of Political Economy, which was founded in the 18th century in Great Britain, reverted to Aristotle's ideas. By investigating the essential of capital, they came to believe that capital takes part in production. In the 20th century, scientists did not attempt to provide a universal definition of capital but formulated a multipolar definition. The mathematics school suggested considering capital as any resource that could be used in the production process. Economists have proposed a definition of capital as resources created by productive activities that are used to the further production of goods and services; goods that are not destined for direct human consumption: investment goods, capital goods (McConnel \& Brue, 2003). Institutionalists have characterized capital as investment wealth, which is measured by the value of the future income that will bring capital to its owners (Korniichuk, Tatarenko \& Poruchnyk, 1999).

Blank (2004) defines capital as economic benefits that have been accumulated as cash reserves and in the form of real capital goods, which are involved by the owners of these benefits in the economic process as an investment resource and a factor of production. The main purpose of using capital as an economic good is to generate income which in the economic system is based on the principles of a market economy and is related to the factor of time, risk and liquidity. In classifying the capital of an enterprise, Blank (2004) distinguishes such forms of capital: financial flows, money, tangible and intangible assets. Paul Theodore Heyne (1993) introduced into economic science the concept of human capital, which allows the efficient use of capital as any form of property. According to the Oxford Dictionary, capital is a good of property (tangible assets) and other assets. Ethan Roland (2015), referring to this definition of capital, proposed to equate "other assets" with "tangible assets," and to consider the financial system and capital as an ecosystem that consists of a number of subsystems as: empirical, intellectual, spiritual, social, material, cultural, basic (providing basic needs) and financial capital. This concept of capital is based on the permaculture principles, which is based on natural relationships in the ecosystem.

\section{Synergistic approach: capital as a multi-functional system}

By analysing the proposed approaches to understanding the nature of capital, it is possible to determine that capital is an extended, multifunctional system, following the example of an ecosystem. The system of capital is formed from the enterprise itself as an economic entity, from property in any form of its manifestation, and from a number of socio-economic components. These are all subsystems that make capital (Figure 1). This symbiosis ensures the continued operation of enterprises at all stages of their life cycle. Each of the subsystems works together and ensures the efficiency of the capital system. Since the main purpose of entrepreneurship is to generate profits, and capital (as a multi-functional system) is the key to successful business, it is possible to identify capital with the enterprise. If any organism or system (as a group of organisms) is forced to adapt to environmental changes in order to survive, the enterprise and capital have to adapt to the current conditions of exposure in order to sustain successful activity.

Considering that the economic system is an openminded dissipation system and that the operating conditions of enterprises in modern economic realities are characterized as unstable and destabilizing, each enterprise has to adapt in one way or another to external and internal influences. Therefore, capital like an enterprise is constantly in a state of adaptation, which is identified with a continuous process of evolution (change or adaptation) like any living organism. It is appropriate to view the process of adaptation as the use of a body of knowledge, skills and experience that are hold by human capital. It is the labour force that is useful and indispensable in ensuring the successful completion of a firm's life cycles. Labour is the link between tangible and intangible values. It is an intellectual capital that makes it possible to assess the level and nature of external influences, and to select and use the necessary mechanism that will enable an adequate response to stress. Therefore, a balanced and motivated use of information and management tools is an essence of the adaptation mechanism (Tevanyan, 2017). 


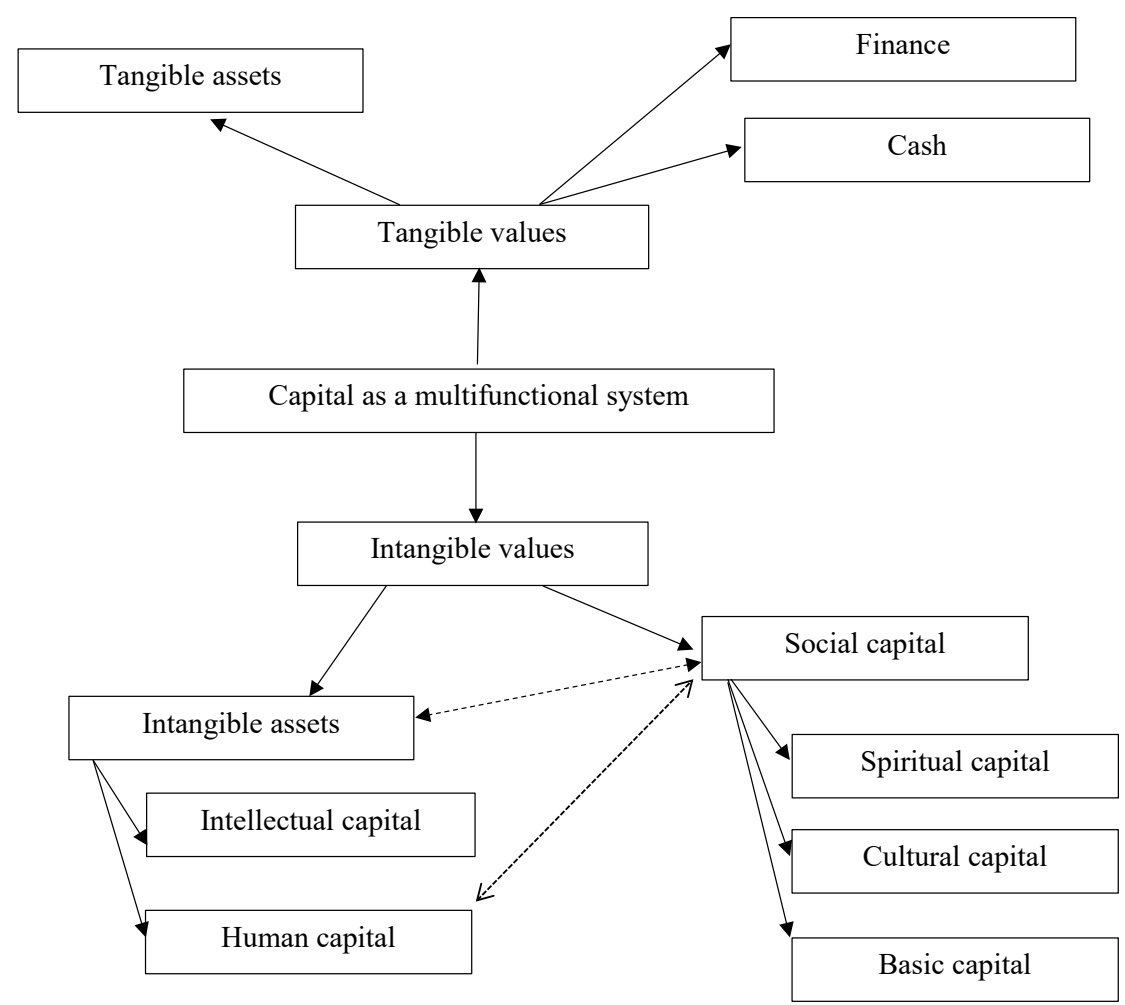

Figure 1. The essence of capital as a multifunctional system

\section{Immediate and long-term adaptation: stages of assessing destabilizing factors}

A distinction needs to be made between immediate adaptation, which enables a rapid response to destabilizing factors, and sustainable (long-term) adaptation. It is sustainable adaptation that identifies potential destabilizing influences on capital (as a multifunctional system) and reflects the negative impacts of externalities in the long run. Changes in financial performance are signals (markers) of immediate adaptation. In turn, systemic (sustainable) adaptation aims at comprehensive change and accommodation of tangible and intangible property. In determining the direction of immediate capital adaptation, these steps should be followed in assessing the conditions of the enterprise:

- assessment and analysis of external influences;

- assessment and analysis of internal influences;

- monitoring of the actual conditions of the enterprise;

- identification of destructive factors;

- identification of sources of potential risks;

- development of ways to minimize the impact of risk factors.

The development of the adaptation mechanism and tools will be possible as a result of the identification of a set of objectives that will emerge from the analysis of the potential challenges and the existence of the "bottlenecks" (the problem spot in the system). To this end, a preliminary assessment of the enterprise's potentials is carried out by using strategic analysis methods and tools (table 1) (Lepeyko \& Kryvobok, 2016).

Strategic analysis focuses on the assessment of external influences on the enterprise, its place in the branch or in the market. From the above proposed methods or tools for estimating and analyzing the externality impact on capital (as a multifunctional system), the economic entity decides at its own discretion, based on the availability of the necessary information. It can be used one method or combination of several ones. The main purpose of the adaptation process is to support an enterprise in a condition that meets the criteria of economic safety at any stage of the business life cycle (Melnik, 2016). The essence of economic security assessment is the ability of an enterprise to withstand potential threats and be able to sustain its own operations and further development (Melikhova, 2018). An economic and mathematical approach can effectively determine the relationship between factors that directly or indirectly affect economic security, assess the degree of influence of these factors, make an analysis, and build a model for strengthening economic security (Koknayeva, 2012).

As mentioned earlier, the main function of a business entity is to make a profit. This means that the formation of a methodological approach for assessing the economic security of capital as a multifunctional system should take into account changes in the profitability indicator (Suvorov, 2001). It is worth noting that the change in financial performance indicators has a correlation with the rate of 
Vol. 2 No. 1, 2021

Table 1

Methods and tools of strategic analysis

\begin{tabular}{|c|c|c|c|c|}
\hline \multirow[b]{2}{*}{$\begin{array}{l}\text { Methods and tools } \\
\text { of analysis }\end{array}$} & \multirow[b]{2}{*}{ Characteristic } & \multicolumn{2}{|c|}{ Area } & \multirow[b]{2}{*}{ Features } \\
\hline & & $\begin{array}{c}\text { External } \\
\text { influencing } \\
\text { factor }\end{array}$ & $\begin{array}{c}\text { Internal } \\
\text { influencing } \\
\text { factor }\end{array}$ & \\
\hline STEEPL- analysis & $\begin{array}{l}\text { It is evaluated an influence on the enterprise of } \\
\text { such factors as: } \\
\text { S (socio-demographic); } \\
\text { T (technological); } \\
\text { E (economical); } \\
\text { E (ecological); } \\
\text { P (political); } \\
\text { L (lawmaking). }\end{array}$ & $\checkmark$ & $x$ & $\begin{array}{l}\text { Helps to identify trends in external } \\
\text { influences on the enterprise. }\end{array}$ \\
\hline SWOT- analysis & $\begin{array}{l}\text { Helps to identify and assess external and } \\
\text { internal influences: } \mathrm{S} \text { (strong points); } \mathrm{W} \text { (weak } \\
\text { points); } \mathrm{O} \text { (opportunities); T (treats). }\end{array}$ & $\checkmark$ & $\checkmark$ & $\begin{array}{l}\text { Enables socio-economic facilities to } \\
\text { be analysed at both the micro and } \\
\text { macro levels. }\end{array}$ \\
\hline SNW- analysis & $\begin{array}{l}\text { Used to assess the internalized environment by } \\
\text { strength, neutrality and weakness. }\end{array}$ & $x$ & $\checkmark$ & $\begin{array}{l}\text { Used as a second step after SWOT- } \\
\text { analysis. }\end{array}$ \\
\hline GAP-analysis & $\begin{array}{l}\text { Used to estimate gaps between current, } \\
\text { maximum, projected and planned enterprise } \\
\text { performances. }\end{array}$ & $\checkmark$ & $\checkmark$ & Helps to adjust business strategy. \\
\hline Industry analysis & $\begin{array}{l}\text { Determines the potential of an industry } \\
\text { in relation to an enterprise according to } \\
\text { economic, consumer, competitive criteria; } \\
\text { assesses the possibility of entering and leaving } \\
\text { the market. }\end{array}$ & $\checkmark$ & $x$ & $\begin{array}{l}\text { It is necessary to obtain information } \\
\text { on the state and prospects of } \\
\text { the industry, technological level, } \\
\text { actual and potential production, } \\
\text { profitability, direct influence on the } \\
\text { enterprise. }\end{array}$ \\
\hline Maps of strategic groups & Useful for assessing competition in the branch. & $\checkmark$ & $x$ & $\begin{array}{l}\text { Allows to predict the profitability } \\
\text { of the enterprise and to adjust the } \\
\text { company development plan. }\end{array}$ \\
\hline Porter's five forces model & $\begin{array}{l}\text { Used to analyse competition in the market } \\
\text { according to such criteria: threat of } \\
\text { substitution products; threat of new entrants } \\
\text { to the market; assessment of the market power } \\
\text { of counterparty; evaluation of the influence } \\
\text { of the buyers on a market; level of existing } \\
\text { competition. }\end{array}$ & $\checkmark$ & $x$ & $\begin{array}{l}\text { Enables the development of a } \\
\text { long-term enterprise development } \\
\text { strategy, taking into account } \\
\text { potential competitive advantages, } \\
\text { which were identified. }\end{array}$ \\
\hline BCG matrix & $\begin{array}{l}\text { Assesses the position of a company in the } \\
\text { market by defining the role of a product in the } \\
\text { market through a product life cycle model. }\end{array}$ & $\checkmark$ & $x$ & $\begin{array}{l}\text { The evaluation takes into account } \\
\text { the performance of the strongest } \\
\text { market participant, allows for the } \\
\text { adjustment of the strategy in the } \\
\text { short or medium term, shaping the } \\
\text { enterprise's tactics. }\end{array}$ \\
\hline ADL matrix & $\begin{array}{l}\text { The matrix is based on the changing life cycle } \\
\text { and competitive position of the enterprise in } \\
\text { the market. }\end{array}$ & $\checkmark$ & $x$ & $\begin{array}{l}\text { Allows to track changes in the } \\
\text { market over time, similar to changes } \\
\text { in the stages of the product life cycle. }\end{array}$ \\
\hline GE analysis & $\begin{array}{l}\text { The analysis takes into account the } \\
\text { attractiveness of the strategic economic zone } \\
\text { and the competitive position. }\end{array}$ & $\checkmark$ & $x$ & $\begin{array}{l}\text { Identifies the highest potential } \\
\text { product. }\end{array}$ \\
\hline Ansoff Matrix & $\begin{array}{l}\text { Built from quadrants of product penetration, } \\
\text { market development, product development, } \\
\text { diversification. }\end{array}$ & $\checkmark$ & $x$ & $\begin{array}{l}\text { Determines the position of the } \\
\text { product in the market. }\end{array}$ \\
\hline Abel matrix & $\begin{array}{l}\text { It helps to define who the consumer is, what } \\
\text { consumers need, how to meet the needs of } \\
\text { consumers. }\end{array}$ & $\checkmark$ & $x$ & $\begin{array}{l}\text { The matrix helps to identify new } \\
\text { consumer needs and meet them by } \\
\text { minimizing production costs. It is } \\
\text { possible to achieve the aim by means } \\
\text { of a synergistic effect during the } \\
\text { search for new market segments. }\end{array}$ \\
\hline
\end{tabular}


development of the enterprise, and at the same time, the guarantee of economic security is equilibrium. Thus, the economic development of the enterprise should be achieved through economic growth, while maintaining the existing level of economic security or by improving performance while maintaining a conditional equilibrium. Accordingly, in the process of capital adaptation, it is important to conduct an economic and mathematical assessment of the financial security of an enterprise, and to take methods of ensuring sustainability or improving financial security indicators as tools for instant adaptation. Financial security assessment is carried out by analyzing the financial condition of the enterprise. For this, vertical and horizontal analysis of absolute indicators of the capital structure and coefficient analysis - express analysis of the financial condition of enterprises are effective.

At the same time, the balance, which is the key to financial stability and security, makes the development of the enterprise impossible. The motivational impetus is precisely the violation of the equilibrium conditions. Instability arises as a consequence of the impact on a heterogeneous (inhomogeneous) system. This proves that economic adaptation should be seen as a synergistic process. Since synergistic systems are self-regulating, adaptation should not be directed towards capital management. The adaptation process should be aimed at creating sustainable positive relationships. The condition for successful synergy is the union of intangible and material values that form a multifunctional system (Kuznetsov, 2004). Combining subsystems into a single system allows you to overcome the dichotomy (plurality) and consider capital as an integral open economic system. It has an internal structure, the dynamics of which is influenced by various factors, both external and internal (Dombrovskyi, 2013).

\section{Conclusions}

Having considered capital as a dissipative multifunctional system that combines intangible and tangible values, social capital, it is worth applying a synergistic approach as understanding the process of capital adaptation. To determine the primary goal of adaptation and assess the state of the enterprise's capital, it is enough to conduct a thorough analysis of external and internal factors of influence, using the methods of strategic analysis and express analysis of the financial condition of the enterprise. As a result (successful adaptation), it is worth considering the creation of effective relationships between the elements of the capital system and irritants of any level, the ability of the system to respond in a timely manner to influencing factors. In the future, it is necessary to investigate ways to assess the state of capital subsystems and classify the factors influencing them in order to develop methods and tools for adapting the components of the capital system.

\section{References:}

Blank, I. (2004). Financial management. Kyiv: Elga Nika Center.

Dombrovskyi, O. (2013). Economic system in terms of synergetics: temporal and spatial context. Efektyvna ekonomika, vol. 2. Available at: http://www.economy.nayka.com.ua/ ?op=1\&z=1788

Heyne, P. (1993). Economic mindset. Moscow: Delo.

Koknayeva, M. (2012). Features of research methodological tools financial security trading companies. Economic Annals-XXI, vol. 5-6, pp. 53-55. Available at: http://soskin.info/en/ea/2012/5-6/contents_16.html

Korniichuk, L., Tatarenko, N., \& Poruchnyk, A. (1999). Economic History. Kyiv: KNEU.

Kuznetsov, B. (2004). Economic synergy as a methodology for economic development. Available at: http://lib.usue.ru/ resource/free/12/s69.pdf

Lepeyko, T., \& Kryvobok, K. (2016). Improving the Tools for Adating Enterprises to Influence of the Competitive Environmental. Business-inform, vol. 12, pp. 176-181.

McConnel, C., \& Brue, S. (2003). Dictionary of Definitions and Terms. Economics. Principles, problems, and policies $\left(4^{\text {th }}\right.$ ed. $)$. Moscow: Infra M.

Melikhova, T. (2018). Assessment of the level of the enterprise financial security as the main component of economic security: a synthesis of existing methodological approaches and critical analysis. Problems of Systemic Approach in the Economy, vol. 1(63), pp. 87-91.

Melnik, M. (2016). Adaptation of an enterprise as backer-up of him economic security. Visnik of the Volodymyr Dahl East Ukrainian National University, vol. 6 (230), pp. 87-90.

Mochernyi, S. (2005). The social and economic essence of capital, Economic theory. Kyiv: Publishing house "Academia".

Palekhova, V. (2007). Evolution of economic thought, Political economy. Mykolaiv: Petro Mohyla Black Sea State University.

Roland, E., \& Landau, G., (2013). Regenerative enterprise. Available at: http://www.regenterprise.com/regenerativeenterprise/

Suvorov, V. (2000). Synergistic concept of organization. Moscow.

Tevanyan, A. (2017). Adaptation of economic system to stress through the medium of intellectual capital management. Journal of Creative Economy, vol. 11(11), pp. 1133-1143. 